\title{
PROSES PEMURNIAN FRAKSI KAYA RHODINOL MINYAK SEREH WANGI MENGGUNAKAN SPINNING BAND DISTILLATION
}

\section{PURIFICATION OF RHODINOL FROM CITRONELLA OIL USING SPINNING BAND DISTILLATION}

\author{
Arum Nur Fitrah $^{1)^{*}}$, Meika Syahbana Rusli ${ }^{1)}$, Dwi Setyaningsih' ${ }^{2)}$, Arief Riyanto ${ }^{2)}$, Nur Hidayati ${ }^{2}$ \\ ${ }^{1}$ Program Studi Teknologi Industri Pertanian, Fakultas Teknologi Pertanian, Institut Pertanian Bogor \\ Kampus IPB Darmaga PO Box 220, Bogor 16002; \\ E-mail: arumfillah@gmail.com \\ ${ }^{2}$ Laboratorium Riset Kimia, Balai Besar Kimia dan Kemasan (BBKK), \\ Jl. Balai Kimia No 1 Pekayon, Pasar Rebo, Jakarta Timur 13710;
}

Makalah: Diterima 3 Juli 2019; Diperbaiki 13 Januari 2020; Disetujui 10 Februari 2020

\begin{abstract}
Indonesia, as one of the biggest countries which supplies citronella oil, has a high potential to produce natural rhodinol. Recent studies on rhodinol purification using fractional and mollecular distillation showed the difficulty of obtaining high purity and yield. The objective of this study was to determine the method of spinning band distillation to purify rhodinol regarding reflux ratio and vaporization temperature. Citronella oil was divided into three fractions according to its boiling points. The volume of each fraction was estimated by its ratio (according to GC analysis) to the feed volume: F1 (components before rhodinol) $21.73 \%$, F2 (rhodinol) $61.7 \%$, and residue 15.82\%. Initial research established the best conditioning before the purification process was $3 \mathrm{mmHg}$ of pressure, equilibration started at $160^{\circ} \mathrm{C}$ in 30 minutes, and $18-17 \%$ of heat rate, as these created the stability of the vapor temperature. The levels of reflux ratio were 3:1 and 5:1, while the evaporation temperatures of rhodinol were $230^{\circ} \mathrm{C}$ and $235^{\circ} \mathrm{C}$. Reflux ratio of $5: 1$ at $230^{\circ} \mathrm{C}$ obtained the highest purity $(81.30 \%)$ and the highest yield $(72.94 \%)$. Equilibration and reflux ratio allowed rectification inside the column because the spinning band homogenized the vapour molecules by its downwards flow and wiped the reflux on the inner surface, which in turn caused the molecules with a lower boiling point to evaporate gradually. Meanwhile the other yields were $79.81 \%$ $\left(3: 1\right.$ at $\left.230^{\circ} \mathrm{C}\right), 80.53 \%\left(3: 1\right.$ at $\left.235^{\circ} \mathrm{C}\right)$, and $80.21 \%\left(5: 1\right.$ at $\left.23^{\circ} \mathrm{C}\right)$ with yields of $71.82 \%, 70.31 \%$, and $68.23 \%$.
\end{abstract}

Keywords: citronella oil, purification, rhodinol, spinning band distillation

\section{ABSTRAK}

Indonesia, salah satu negara penghasil minyak sereh wangi terbesar di dunia, memiliki potensi yang tinggi untuk memproduksi rhodinol. Penelitian sebelumnya mengenai pemurnian rhodinol dari minyak sereh wangi menggunakan fraksinasi vakum dan distilasi molekular, belum menghasilkan kadar dan rendemen yang tinggi. Tujuan penelitian ini adalah mengetahui metode penggunaan alat distilasi pita putar yang tepat untuk memurnikan rhodinol terhadap variabel rasio refluks dan suhu penguapan rhodinol. Fraksi kaya rhodinol yang digunakan diuji $G C$ lalu dibagi menjadi tiga fraksi berdasarkan titik didih komponennya. Diperoleh fraksi ringan sebanyak 21,73\% $(\mathrm{v} / \mathrm{v})$, fraksi rhodinol $61,7 \%(\mathrm{v} / \mathrm{v})$, dan residu $15,82 \%(\mathrm{v} / \mathrm{v})$. Volume tiap fraksi dihitung dengan mengalikan kadar fraksi dengan volume bahan. Kondisi proses terbaik berdasarkan penelitian pendahuluan adalah pada suhu potong F1 $160^{\circ} \mathrm{C}$, tekanan $3 \mathrm{mmHg}$, laju panas $18-17 \%$, dan kesetimbangan 30 menit sebab menghasilkan grafik suhu penguapan yang stabil pada tiap fraksi. Variabel rasio refluks yang digunakan adalah 3:1 dan 5:1 dengan suhu penguapan $230^{\circ} \mathrm{C}$ dan $235^{\circ} \mathrm{C}$. Variabel 5:1 pada $230^{\circ} \mathrm{C}$ menghasilkan kadar dan rendemen rhodinol tertinggi yaitu $81,30 \%$ dan $72,94 \%$. Semakin tinggi waktu kesetimbangan dan rasio refluks, semakin murni distilat yang dihasilkan karena pengadukan ke arah bawah menyebabkan molekul uap dan refluks saling bertumbukan sepanjang kolom sehingga terjadi perpindahan panas dari molekul bertitik didih lebih tinggi ke molekul bertitik didih lebih rendah, penguapan menjadi lebih terseleksi. Pada rasio refluks dan suhu penguapan lain, dihasilkan kadar rhodinol sebesar 79,81\% $\left(3: 1 ; 230^{\circ} \mathrm{C}\right), 80,53 \%\left(3: 1 ; 235^{\circ} \mathrm{C}\right)$, dan $80,21 \%\left(5: 1 ; 235^{\circ} \mathrm{C}\right)$ dengan rendemen berturut-turut $71,82 \%, 70,31 \%$, dan $68,23 \%$.

Kata kunci: pemurnian, rhodinol, minyak sereh wangi, distilasi pita putar

\section{PENDAHULUAN}

Indonesia merupakan penghasil minyak sereh wangi nomer tiga terbesar di dunia setelah Cina dan Vietnam dengan perkiraan produksi 350 ton/tahun (Rusli, 2010). Minyak sereh wangi terdiri dari tiga komponen utama yaitu sitronelal, sitronelol, dan geraniol. Sitronelal dan geraniol memiliki titik didih yang berdekatan sehingga sulit dipisahkan, campuran keduanya disebut rhodinol. Rhodinol banyak dimanfaatkan sebagai bahan baku pewangi, aromaterapi, perisa, farmasi, kosmetik, komponen 
penyusun minyak mawar, pengusir nyamuk, dan bioaditif bahan bakar minyak (Sulaswatty et al., 2019). Rhodinol yang biasa diperdagangkan di pasar dunia diperoleh dari Geranium sp, namun tanaman ini tidak umum tumbuh di Indonesia. Rhodinol dari sereh wangi memiliki penampakan jernih, tidak berwarna sampai kuning pucat, memiliki aroma paduan bunga, mawar, dan wanginya seperti geranium (Brechbill, 2009). Rhodinol juga dapat dihasilkan dari minyak bumi atau diekstraksi melalui reaksi kimia seperti hidrolisis geranil asetat menjadi geraniol dengan larutan $\mathrm{NaOH}$ dalam etanol (Sayekti et al., 2013), penambahan natrium bisulfit (Muyassaroh, 2010), oksidasi dengan $\mathrm{KMnO}_{4}$ (Amanatur et al., 2014), atau oksidasi dengan hidrogen peroksida dan platinum (Weng et al., 2015). Meskipun dapat diperoleh rhodinol hingga $90 \%$, produk tergolong sintetis dan dapat menyisakan kontaminan yang dapat berdampak pada kesehatan jangka panjang, serta membutuhkan biaya lebih pada pengolahan limbah dan penyediaan bahan kimia.

Umumnya Indonesia mengekspor minyak sereh wangi dalam bentuk mentah karena minimnya pengetahuan dan teknologi yang dimiliki industri kecil, dan mengimpor kembali senyawa turunannya yang lebih murni, rata-rata ekspor minyak sereh wangi tahun 2008 - 2012 senilai 27.069.200 US\$ sedangkan impor produk turunannya senilai 460.600 US\$ (Dirjen Perkebunan, 2013). Prospek dan potensi pasar minyak sereh wangi dan turunannya cenderung stabil dan terus meningkat karena minyak ini banyak dibutuhkan (Rusli, 2015). Dengan demikian, rhodinol sangat potensial dihasilkan di Indonesia untuk meningkatkan nilai tambah minyak sereh wangi, menambah pendapatan masyarakat di sektor pertanian (Sulaswatty et al., 2019), dan menambah devisa negara.

Rangkaian penelitian yang telah dilakukan sebelumnya terdapat pada Sulaswatty et al. (2019), komponen minyak sereh wangi diisolasi melalui pemisahan fisika menggunakan metode distilasi molekular atau short path distillation (SPD) dan fraksinasi vakum namun, kadar dan recovery yang dihasilkan belum tinggi. Kadar rhodinol yang dihasilkan dari metode SPD dengan kondisi proses feed 1-2 tetes/detik, suhu $58-62^{\circ} \mathrm{C}$, kenaikan suhu $1^{\circ} \mathrm{C}$, dan kecepatan $200 \mathrm{rpm}$ hanya sebesar $60,46 \%$ dari kadar bahan $41,44 \%$, dengan loss sebesar $9 \%$. Pada kondisi proses yang berbeda, yaitu feed 0,029 g/detik, suhu $64-68^{\circ} \mathrm{C}$, kenaikan suhu $2^{\circ} \mathrm{C}$, kecepatan $200 \mathrm{rpm}$, dan tekanan $10-3 \mathrm{mbar}$, diperoleh kadar rhodinol sebesar $89,01 \%$ dari kadar bahan $71,19 \%$ namun rendemennya hanya $3,86 \%$ karena terdapat komponen ester yang sulit dipisahkan. Metode fraksinasi vakum minyak sereh wangi yang dilakukan pada tekanan $4-5$ mbar, rasio refluks conditioning $30: 1$, dan rasio refluks fraksi utama $10: 10$ menghasilkan kadar sitronelal sebesar $90,67 \%$ dan rhodinol $67,09 \%$. Redistilasi rhodinol dilakukan dengan rasio refluks conditioning $10: 1$ dan $10: 5$, sehingga diperoleh kadar rhodinol sebesar $79,30 \%$ dengan rendemen 19,88\%. Proses tersebut dilanjutkan menggunakan SPD dengan feed $(76,43 \%)$ 1 tetes/detik, tekanan $1-3$ mbar, kenaikan $2{ }^{\circ} \mathrm{C}$, dan kecepatan $300 \mathrm{rpm}$. Pada suhu $56-60^{\circ} \mathrm{C}$ dihasilkan kadar rhodinol $77,07 \%$ dengan rendemen $90,77 \%$ sedangkan pada suhu $64-68^{\circ} \mathrm{C}$ dihasilkan kadar rhodinol $82,45 \%$ dengan rendemen $57,75 \%$.

Spinning band distillation column merupakan teknologi pemisahan baru yang dapat memisahkan komponen bertitik didih berdekatan (hingga $0,5^{\circ} \mathrm{C}$ ) dan sensitif terhadap panas. Alat ini memiliki kolom dengan pita berpilin di tengahnya yang menghasilkan putaran ke arah bawah sehingga membuat keadaan menjadi homogen dan pemisahan lebih terselektif dengan adanya transfer panas antar molekul dan transfer massa sepanjang kolom. Putaran pita menciptakan jumlah plat teoritis yang tinggi sehingga tinggi kolom spinning band jauh lebih pendek dibandingkan kolom fraksinasi biasa. Kelebihan alat spinning band distillation ini antara lain efisiensinya tinggi, minimum loss, hold up rendah, pressure drop rendah, aman dari flooding, serta minimal risiko kerusakan bahan akibat panas (Ozek, 2013; Song-lin et al., 2019). Penggunaan alat juga dapat mengurangi volume limbah karena dapat memurnikan pelarut yang telah digunakan sebagai pencuci alat atau pelarut sampel sehingga dapat digunakan ulang (Gibbs, 1983). Tujuan penelitian ini adalah mengetahui suhu potong, tekanan, laju panas, dan waktu kesetimbangan yang tepat untuk conditioning alat sebelum proses pemisahan berlangsung serta mengetahui pengaruh rasio refluks dan suhu potong fraksi rhodinol terhadap kemurnian dan recovery rhodinol yang dihasilkan.

\section{BAHAN DAN METODE}

\section{Bahan dan Alat}

Bahan-bahan yang digunakan antara lain fraksi kaya rhodinol dari hasil fraksinasi minyak sereh wangi jenis Mahapengiri (Java citronella oil) yang diperoleh dari PT Indesso Aroma Cileungsi, toluen, etanol teknis $96 \%$, cold trap (garam, air, dan es batu), vaselin, dan batu didih. Peralatan yang digunakan mencakup spinning band distillation column tipe 9600 B/R Instrument (Lab. Riset Kimia - Balai Besar Kimia dan Kemasan) yang dilengkapi program M690PCRev1.exe, chiller, dan vakum; gelas ukur; wadah penampung; dan Gas Chromatography (GC) Agilent 7890A (PT Indesso Aroma Cileungsi). Skema spinning band distillation column dapat dilihat pada Gambar 1. 

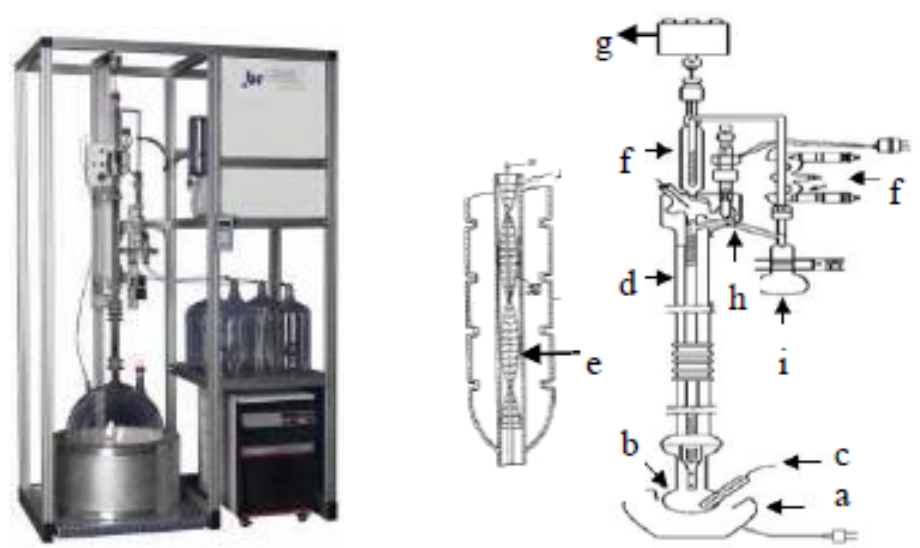

Keterangan:

a) pemanas

b) labu feed

c) termokopel

d) kolom

e) pita putar

f) kondensor

g) motor

h) katup refluks

i) labu distilat

Gambar 1. Spinning band distillation column 9600 B/R Instrument. Sumber: BR Instrument (2014), Yost (1974), Ozek (2013)

\section{Metode}

Pada penelitian Amrullah et al. (2017), dilakukan isolasi patchouli alcohol dari minyak nilam menggunakan alat spinning band distillation model 36-100 B/R Instrument, sedangkan Riyanto et al. (2012) melakukan isolasi metil sinamat dari minyak atsiri laja gowah menggunakan alat spinning band distillation model $9400 \mathrm{~B} / \mathrm{R}$ Instrument. Penelitian tersebut menjadi acuan pada tahapan penelitian ini, yaitu: karakterisasi minyak; analisis pergerakan suhu untuk menentukan suhu potong fraksi pertama, tekanan, laju panas, dan waktu kesetimbangan; serta penentuan rasio refluks dan suhu potong pada fraksi utama.

\section{Karakterisasi Minyak}

Karakterisasi mencakup analisis GC untuk uji kemurnian bahan baku serta uji kadar untuk mengetahui komposisi pada bahan, distilat, dan residu. Analisis GC dilakukan di PT Indesso Aroma Cileungsi. Uji kadar komposisi dengan GC menggunakan sampel setiap fraksi dan ulangannya sebanyak $1 \mu \mathrm{L}$ dengan kondisi operasi sebagai berikut:

a. Injektor

Mode injeksi

Suhu

: Split (rasio split $=100: 1)$

Gas karier

Laju total

$: 275^{\circ} \mathrm{C}$

: Nitrogen

: $0,5 \mathrm{~mL} / \mathrm{menit}$

b. Kolom

Tipe

Model

: Kolom non polar

: HP-1 (Methyl siloxane)

c. Oven

Suhu awal $\quad: 100{ }^{\circ} \mathrm{C}$

Kesetimbangan : 5 menit

d. Program Suhu

Laju

Suhu akhir

: $5^{\circ} \mathrm{C} /$ menit

$: 300^{\circ} \mathrm{C}$

Durasi suhu akhir : 15 menit

Total program : 40 menit

e. Detektor

Suhu

: $275^{\circ} \mathrm{C}$
Makeup gas
: nitrogen
Makeup flow
: $25 \mathrm{~mL} / \mathrm{menit}$
Laju $\mathrm{H}_{2}$
: $30 \mathrm{~mL} / \mathrm{menit}$
Laju udara
: $400 \mathrm{~mL} / \mathrm{menit}$

Kromatogram hasil $G C$ pada bahan digunakan untuk menentukan lokasi pemotongan fraksi rhodinol berdasarkan lokasi peak. Lalu kadar tiap fraksi dijumlahkan berdasarkan total luas daerah peak yang ada pada setiap fraksi. Kadar tiap fraksi menjadi acuan dalam menentukan volume tiap fraksi yang akan diisolasi dengan cara mengalikan kadar tiap fraksi dengan volume feed yang digunakan.

\section{Analisis Pergerakan Suhu Terhadap Waktu Proses}

Pencucian alat dilakukan menggunakan etanol dan toluen. Fraksi kaya rhodinol $500 \mathrm{~mL}$ dimasukan ke dalam labu feed. Analisis pergerakan suhu terdiri dari penentuan suhu potong, tekanan, laju panas, dan waktu kesetimbangan.

\section{Penentuan Suhu Potong Fraksi}

Suhu potong merupakan besaran suhu pada kolom atas yang menjadi acuan untuk dimulainya proses kesetimbangan dan buka-tutup katup refluks. Besaran suhu potong tiap fraksi ditentukan berdasarkan titik didih komponen yang ingin dipisahkan. Titik didih fraksi penyusun minyak sereh wangi dari beberapa literatur dapat dilihat pada Tabel 1.

Data empiris tersebut dikonversi menggunakan program BR AET Utility 0,1 yang terhubung dengan alat sehingga nilainya sesuai dengan keadaan kolom yang digunakan, dimana besaran suhu pada 1 atm dikonversi ke besaran suhu pada satuan mmHg yang digunakan pada alat, sedangkan satuan mmHg dari data empiris dikonversi ke AET. AET (Atmospheric Equivalent Temperature) merupakan hasil konversi suhu puncak kolom pada tekanan aktual dalam kolom ke besaran suhu pada tekanan $1 \mathrm{~atm}(760 \mathrm{mmHg})$. 
Tabel 1. Titik didih $\left({ }^{\circ} \mathrm{C}\right)$ fraksi utama berdasarkan data empiris dan hasil konversi

\begin{tabular}{llll}
\hline Titik didih $\left({ }^{\circ}\right.$ C) pada: & Sitronelal & Sitronelol & Geraniol \\
\hline 1. Tekanan $1 \mathrm{~atm}$ & $206,5^{\mathrm{a}} ; 204-208^{\mathrm{b}}$ & $221,5^{\mathrm{a}} ; 225^{\mathrm{c}} ; 225-226^{\mathrm{d}}$ & $230^{\mathrm{abd}}$ \\
Konversi ke 4 mmHg & 65,$6 ; 63,7-66,8$ & 77,$3 ; 80 ; 80-80,8$ & 83,9 \\
Konversi ke 3 mmHg & 60,$7 ; 58,8-61,8$ & 72,$2 ; 74,9 ; 75,7$ & 78,8 \\
2. Tekanan 4 mmHg & 64,55 & 86,8 & 89,9 \\
Konversi ke AET & 205,2 & 233,7 & 237,7 \\
3. Tekanan 3 mmHg a & 57,7 & 8 & 83 \\
Konversi ke AET & 202,6 & 231,6 & 235,5 \\
\hline
\end{tabular}

Sumber: a Perry dan Green (1999), ${ }^{b}$ Maloney (2008), ${ }^{c}$ US EPA (2009), ${ }^{d}$ Kirk (1954) diacu dalam

Ketaren (1985)

Berdasarkan data empiris dan konversi tersebut, dilakukan trial pemotongan fraksi pada titik suhu $210^{\circ} \mathrm{C}, 225^{\circ} \mathrm{C}, 230^{\circ} \mathrm{C}$, dan $240^{\circ} \mathrm{C}$. Nilai suhu potong yang diinput pada program adalah sebagai suhu AET. Kemudian dilakukan uji GC pada tiap suhu potong. dan $4 \mathrm{mmHg}$.

\section{Penentuan Tekanan}

Tekanan diuji melalui trial dan berdasarkan data penelitian sebelumnya, yaitu $4-5$ mbar (Sulaswatty et al., 2019). Satuan mbar dikonversi ke dalam satuan $\mathrm{mmHg}$ sehingga digunakan variabel tekanan 3 dan $4 \mathrm{mmHg}$.

\section{Penentuan Laju Panas}

Laju panas merupakan persentase panas yang digunakan dari total kapasitas energi pada kompor. Laju panas diatur pada tahap pemanasan, kesetimbangan, distilasi fraksi awal, dan distilasi fraksi rhodinol secara trial error yang dimulai dari $20 \%$. Laju panas dipilih yang dapat menghasilkan AET yang stabil pada suhu titik potong tiap fraksi.

\section{Penentuan Waktu Kesetimbangan}

Kesetimbangan merupakan tahap setelah pemanasan, saat AET mencapai suhu potong awal fraksi ringan sehingga pita kolom mulai berputar namun katup refluks masih tertutup (total refluks). Suhu potong, tekanan, dan laju panas yang diterapkan sesuai dengan hasil tahap penelitian sebelumnya. Waktu kesetimbangan yang diuji adalah 5, 15, dan 30 menit (Amrullah et al., 2017). Setelah kesetimbangan selesai, katup refluks mulai bekerja. Pada tahap ini digunakan rasio refluks $1: 1$. Waktu kesetimbangan dipilih yang dapat menghasilkan suhu penguapan yang stabil serta kadar rhodinol tertinggi.

\section{Analisis Rasio Refluks dan Suhu Potong terhadap Kadar dan Rendemen Rhodinol}

Rasio refluks merupakan perbandingan waktu tutup dan waktu buka katup refluks dalam satuan detik. Rasio refluks diterapkan pada fraksi ringan dan fraksi rhodinol dengan nilai yang sama, variabel yang digunakan sebesar $3: 1$ dan $5: 1$ berdasarkan trial. Variabel suhu potong fraksi rhodinol dipilih berdasarkan hasil uji penentuan suhu potong. Rasio refluks dan suhu potong fraksi rhodinol (suhu penguapan rhodinol) dipilih yang dapat menghasilkan kadar, rendemen, dan recovery rhodinol tertinggi. Kadar rhodinol diperoleh dari uji GC, sedangkan rendemen dan recovery diperoleh dengan menghitung neraca massa.

Neraca massa dihitung berdasarkan hukum kekekalan massa, yaitu massa yang masuk sama dengan massa yang keluar. Massa yang masuk berupa fraksi kaya rhodinol pada feed, sedangkan massa yang keluar merupakan seluruh fraksi distilat dan residu. Fraksi hasil dan residu yang diperoleh diukur volumenya. Untuk mengubah satuan volume ke dalam massa, volume dikalikan dengan densitas/massa jenis rhodinol ( $\rho$ rhod) sebesar 0,865 $\mathrm{g} / \mathrm{mL}$. Rendemen rhodinol merupakan jumlah rhodinol (g) yang dihasilkan pada fraksi rhodinol, diperoleh dengan mengkalikan massa fraksi dengan kadar rhodinol. Perhitungan neraca massa rhodinol dilakukan dengan rumus berikut:

massa in = massa out

A . x . $\rho \operatorname{rhod}=\sum$ B. y. $\rho \operatorname{rhod}+$ R. z. $\rho \operatorname{rhod}$

Dimana,

A $=$ volume fraksi kaya rhodinol (feed)

$\mathrm{x}=$ kadar komponen rhodinol pada feed

$\rho$ rhod $=0,865 \mathrm{~g} / \mathrm{mL}$

$\mathrm{B} \quad=$ volume fraksi hasil

y $\quad=$ kadar komponen rhodinol pada fraksi hasil

$\mathrm{R} \quad=$ residu

$\mathrm{Z} \quad=$ kadar komponen rhodinol pada residu

Maka neraca massa rhodinol yang diperoleh adalah:

A . $x \cdot \rho \operatorname{rhod}=\sum$ B. $y . \rho \operatorname{rhod}+$ R. z. $\rho \operatorname{rhod}$

A mL .x\%. 0,865 g/mL = $\sum$ B mL. $y \% .0,865 \mathrm{~g} / \mathrm{mL}$

$+\mathrm{R}$ mL. $\mathrm{z} \% \cdot 0,865 \mathrm{~g} / \mathrm{mL}$

$\frac{0,865 \cdot A \cdot x}{100} \mathrm{~g}=\sum \frac{0,865 \cdot B \cdot y}{100} \mathrm{~g}+\frac{0,865 \cdot R \cdot z}{100} \mathrm{~g}$

Apabila massa out yang dihasilkan lebih kecil dari massa in, maka terdapat massa yang hilang (loss) 
selama proses. Loss dihitung dengan mengurangi massa in dengan massa out.

$$
\begin{aligned}
& \operatorname{Loss}(\mathrm{g})=\text { massa in }(\mathrm{g})-\text { massa out }(\mathrm{g}) \\
& \operatorname{Loss}(\%)=100 \%-\text { out }(\%) \\
& \text { Out }(\%)=\frac{\sum \text { Fraksi hasil }+ \text { Residu }}{\text { Feed atau massa } \text { in }} \times 100 \%
\end{aligned}
$$

Recovery rendemen rhodinol merupakan persentase perolehan rendemen rhodinol terhadap jumlah rhodinol pada feed. Perhitungan recovery adalah sebagai berikut:

$$
\text { Recovery rhodinol }(\%)=\frac{\text { Rendemen rhodinol }(\mathrm{g})}{\mathrm{x} \text {. } 100 \%}
$$

\section{HASIL DAN PEMBAHASAN}

\section{Karakterisasi Minyak}

Minyak yang digunakan merupakan fraksi dari minyak sereh wangi jenis mahapengiri (Java citronella oil) yang diperoleh dari Cymbopogon winterianus Jowitt. Minyak jenis ini dipilih karena memiliki kadar geraniol yang lebih tinggi dari jenis lainnya, yaitu sebesar $65-90 \%$ dan sitronelal $30-$ $45 \%$, sedangkan jenis Lenabatu (Ceylon citronelal oil) yang berasal dari Cymbopogon nardus Rendle hanya mengandung geraniol $55-65 \%$ dan sitronelal 7 - 15\% (Sulaswatty et al., 2019). Rhodinol minyak sereh wangi biasanya berwarna kuning pucat sampai kuning kecoklatan (BSN, 1995). Warna sitronelal adalah bening kekuningan BSN (1987a) dan geraniol berwarna bening hingga kecoklatan BSN (1987b). Fraksi kaya rhodinol sebagai bahan baku yang diperoleh dari pabrik sudah melalui serangkaian uji quality control, mencakup uji kemurnian dan kadar menggunakan alat GC.

Minyak yang diperoleh merupakan minyak murni tanpa bahan asing/adulterant dengan warna bening kekuningan. Minyak atsiri tidak boleh mengandung bahan asing seperti minyak lemak, alkohol, atau pun minyak tanah (Harris, 1994). Kualitas minyak sereh wangi ditentukan oleh karakteristik alamiah dari masing-masing senyawa dan bahan-bahan asing akan merusak mutu minyak sehingga nilai jualnya turun. Kualitas dan nilai jual minyak harus ditingkatkan dengan cara dimurnikan. Pemurnian secara fisika memerlukan peralatan penunjang yang spesifik, sedangkan pemurnian kimiawi dapat dilakukan dengan alat yang lebih sederhana namun menghasilkan limbah, kontaminan, serta membutuhkan bahan kimia lain. Proses pemurnian meningkatkan kualitas pada warna, sifat fisikokimia, dan kadar komponen utamanya (Djazuli, 2009).

Hasil GC bahan baku pada Gambar 2 menunjukkan peak fraksi rhodinol berada di tengah kromatogram sehingga dilakukan pemotongan pada fraksi depan dan belakang untuk memurnikan rhodinol. Berdasarkan jumlah luas area tiap komponen, diketahui bahwa jumlah fraksi depan (komponen sebelum sitronelal) adalah sebesar 0,069\%; komponen sitronelal (pada peak ke tiga) adalah sebesar $0,574 \%$; komponen minor antara sitronelal dan sitronelol (Sao) seperti linalool, isopulegol I, dan isopulegol II adalah sebesar 21,086\%; komponen sitronelol dan geraniol sebagai fraksi utama adalah sebesar $20,14 \%$ dan $41,56 \%$; sedangkan residu terdiri dari sitronelil asetat, geranil asetat, $\beta$-kariofilen, dan komponen minor lainnya adalah sebesar 15,815\%. Kadar sitronelol dan geraniol dijumlahkan sehingga diperoleh kadar rhodinol sebesar $61,7 \%$. Namun demikian, masih terdapat beberapa komponen minor di antara sitronelol dan geraniol sehingga dapat mempengaruhi kadar fraksinya setelah diisolasi.

Dari pemotongan fraksi tersebut, maka diperoleh tiga jenis fraksi yang akan dipisahkan melalui proses distilasi yaitu, fraksi ringan (sebelum sitronelal), fraksi rhodinol, dan residu (setelah geraniol). Volume tiap fraksi tersebut dihitung dengan mengalikan kadar tiap fraksinya dengan volume feed sebesar $500 \mathrm{~mL}$ sehingga diperoleh hasil seperti pada Tabel 2. Perhitungan volume ini digunakan sebagai acuan atau batas maksimal volume distilat yang dikumpulkan pada setiap fraksinya. Dengan kata lain, jika volume fraksi ringan telah tercapai maka dilakukan pengumpulan distilat pada botol fraksi selanjutnya yaitu fraksi rhodinol.

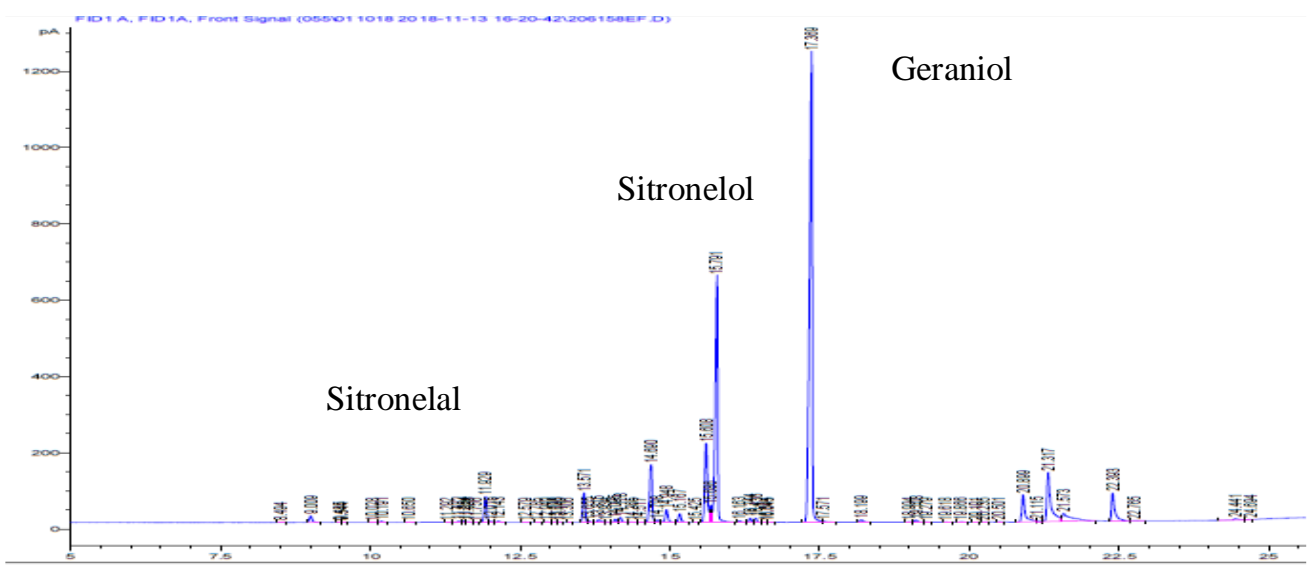

Gambar 2. Kromatogram hasil uji GC bahan fraksi kaya rhodinol minyak sereh wangi 
Tabel 2. Perhitungan volume tiap fraksi pada feed $500 \mathrm{~mL}$

\begin{tabular}{lcccccc}
\hline \multirow{2}{*}{ Feed 500 $\mathbf{~ m L}$} & \multicolumn{3}{c}{ Fraksi ringan } & \multicolumn{2}{c}{ Fraksi rhodinol } & Residu \\
\cline { 2 - 7 } & Awal & Sa & Sao & So & Go & Akhir \\
\hline Kadar hasil $G C(\%)$ & 0,069 & 0,574 & 21,086 & 20,144 & 41,556 & 15,815 \\
Kadar* $500=\ldots(\mathrm{mL})$ & 0,35 & 2,87 & 105,43 & 100,72 & 207,78 & 79,08 \\
Volume fraksi $(\mathrm{mL})$ & \multicolumn{3}{c}{108,65} & \multicolumn{2}{c}{308,50} & 79,08 \\
\hline
\end{tabular}

Keterangan: Awal $=$ sebelum sitronelal, $\mathrm{Sa}=$ sitronelal, $\mathrm{Sao}=$ antara sitronelal dan sitronelol, So $=$ sitronelol, Go $=$ geraniol, Akhir $=$ setelah geraniol .

\section{Hubungan Suhu Potong, Tekanan, Laju Panas, dan Waktu Kesetimbangan terhadap Pergerakan Suhu dan Kadar Rhodinol}

Pada proses distilasi, terdapat variabelvariabel penting yang memengaruhi fraksi yang dihasilkan antara lain, suhu, tekanan, keadaan kolom, dan rasio refluks. Penentuan suhu distilasi dapat berupa titik didih komponen yang ingin dipisahkan. Penentuan tekanan mampu memengaruhi kualitas distilat yang dihasilkan (Amrullah et al., 2017).

Pada penelitian ini, uji pergerakan suhu dilakukan untuk memvalidasi suhu penguapan aktual komponen-komponen minyak pada variabel yang digunakan (Riyanto et al., 2012). Laju panas akan memengaruhi kecepatan penguapan tiap komponen, semakin besar lajunya maka akan semakin cepat suhu naik. Komponen menguap melewati kolom secara bertahap sesuai titik didihnya, suhu AET akan naik hingga mencapai suhu potong fraksi ringan. Uap terkondensasi pada kondensor menjadi kondensat, lalu mengalir ke katup refluks. Saat katup refluks terbuka, kondensat mengalir ke labu distilat sedangkan saat katup tertutup, kondensat kembali turun membentuk lapisan refluks pada permukaan dalam kolom. Pada tahap kesetimbangan, katup refluks terus tertutup sehingga terjadi total refluks pada kolom. Pada tahap pemasanan dan kesetimbangan, suhu AET perlu dijaga agar berada di bawah titik didih rhodinol agar saat katup refluks terbuka, pemotongan fraksi pertama dapat dilakukan pada suhu potong fraksi ringan.

Pengujian suhu potong dilakukan dengan pemotongan fraksi di beberapa titik suhu dengan laju panas bertingkat (naik bertahap) hingga feed habis, kemudian dilakukan uji GC untuk melihat perubahan kadar komponen berdasarkan pergerakan suhunya. Grafik ditunjukkan pada Gambar 3 dengan feed 500 $\mathrm{ml}$, laju panas awal $20 \%, E q$ (equilibration) atau kesetimbangan selama 1 menit, suhu potong pertama pada $200^{\circ} \mathrm{C}$, dan tekanan $4 \mathrm{mmHg}$. Tpot (Temperature of pot) merupakan suhu pada wadah feed, sedangkan Tv (Temperature of vapor) merupakan suhu uap di kolom atas pada tekanan actual.

Pada Gambar 3, kesetimbangan terjadi pada menit ke-49 yang disimbolkan dengan “ $E q$ ", laju panas fraksinasi dinaikan menjadi $25 \%$ pada menit ke-50, 30\% pada menit ke-60, hingga 50\% pada menit ke-180 untuk menghabiskan semua feed. Apabila laju panas tidak ditingkatkan, suhu AET lama-kelamaan menjadi turun. Pada tahap kesetimbangan, suhu menunjukkan nilai di atas $230^{\circ} \mathrm{C}$ sehingga melewati titik didih fraksi sitronelal, artinya laju panas awal perlu diturunkan. Oleh karena itu, dilakukan percobaan laju panas yang stabil pada $20 \%$. Pemotongan fraksi diuji pada beberapa titik suhu untuk mengetahui perubahan kadar dan rendemen rhodinol sesuai suhunya (Yao dan Hammond, 2006). Volume tiap fraksi serta kadar dan rendemen rhodinol pada tiap fraksi (neraca massa) ditunjukkan pada Tabel 3.

Hasil uji menunjukkan kadar dan rendemen rhodinol yang paling tinggi diperoleh pada F230 dan F240. Pada F230 diperoleh kadar rhodinol sebesar $74,86 \%$ dengan rendemen 129,51 g (60,66\%) sedangkan pada F240 diperoleh kadar rhodinol sebesar 78,87\% dengan rendemen 42,64 g (19,97\%). Hal ini menunjukkan bahwa rhodinol dapat mulai diisolasi pada suhu $230^{\circ} \mathrm{C}$. Namun demikian, fraksi ringan (komponen sebelum rhodinol) masih diperoleh cukup banyak sampai F240. Oleh karena itu, untuk mengisolasi fraksi ringan tersebut di awal fraksi, dibutuhkan laju panas yang lebih rendah di awal proses agar suhu stabil pada suhu $<225^{\circ} \mathrm{C}$ sehingga fraksi ringan menguap dan habis terlebih dahulu.

Laju panas diturunkan menjadi 20\% - 16\%, suhu potong pertama diturunkan menjadi $160^{\circ} \mathrm{C}$ hingga $230^{\circ} \mathrm{C}$, tekanan diturunkan pada $3 \mathrm{mmHg}$, waktu kesetimbangan diperpanjang selama 10 menit, dan digunakan rasio refluks $1: 1$. Tekanan yang lebih rendah dapat menghasilkan kadar yang lebih tinggi dan proses yang lebih cepat karena suhu penguapan turun (Beneti et al., 2011). Ferdayanti et al. (2016) dan Sayekti et al. (2013) juga melakukan fraksinasi komponen minyak sereh wangi pada tekanan 3 mmHg. Tabel 4 menunjukkan pengaruh penurunan laju panas pada setiap tahap (pemanasan, kesetimbangan, dan distilasi fraksi ringan) terhadap suhu AET dan volume fraksi ringan yang dihasilkan.

Volume feed diturunkan menjadi $300 \mathrm{~mL}$ karena pada volume $500 \mathrm{~mL}$ dibutuhkan waktu isolasi fraksi ringan yang terlalu panjang (5 jam). Dengan demikian, perolehan volume tiap fraksi dengan 300 $\mathrm{mL}$ feed juga diubah seperti pada Tabel 5. 


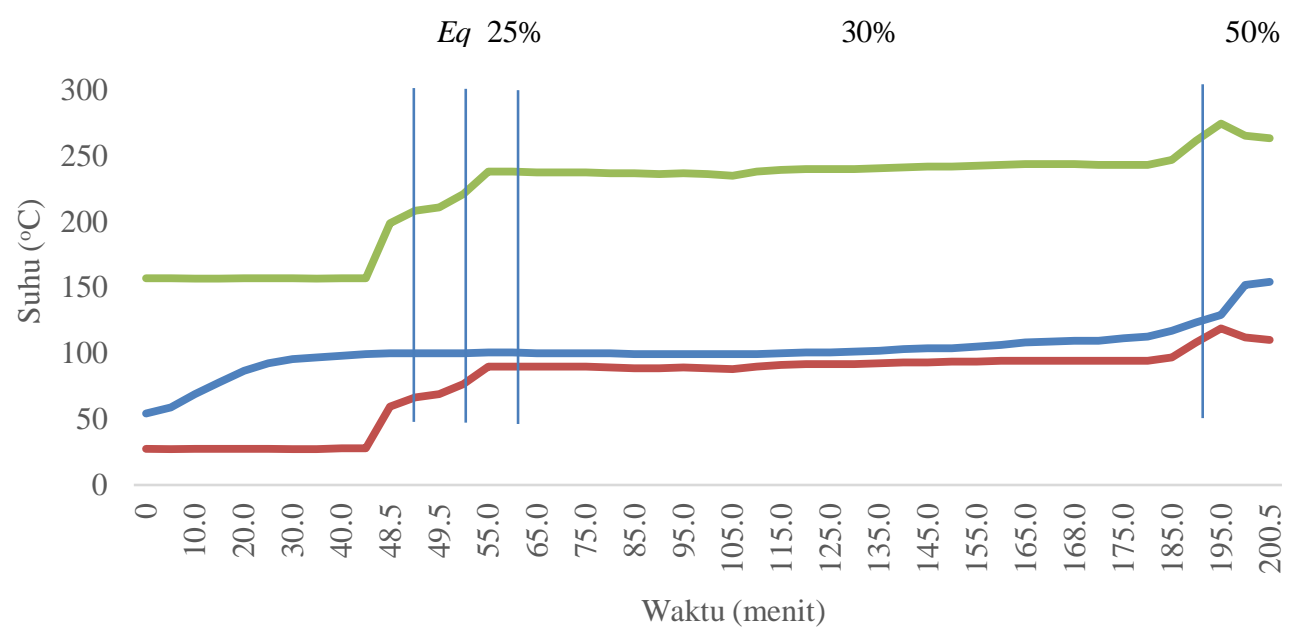

Gambar 3. Grafik suhu terhadap perlakuan laju panas bertingkat

Tabel 3. Perhitungan neraca massa proses distilasi pada tahap uji suhu potong dengan laju panas $20 \%$

\begin{tabular}{|c|c|c|c|c|c|c|c|c|c|}
\hline \multicolumn{4}{|c|}{ Feed (in) } & \multicolumn{5}{|c|}{ Fraksi hasil distilasi (out) } & \multirow[b]{3}{*}{$\begin{array}{l}\begin{array}{l}\text { Recovery } \\
\text { rhodinol } \\
(\%)\end{array}\end{array}$} \\
\hline \multirow{2}{*}{$\begin{array}{l}\text { Vol. } \\
\text { Feed } \\
\text { (mL) }\end{array}$} & \multicolumn{3}{|c|}{ Rhodinol awal } & \multirow[b]{2}{*}{$\begin{array}{c}\text { Fraksi } \\
\left({ }^{\circ} \mathrm{C}\right)\end{array}$} & \multirow[b]{2}{*}{$\begin{array}{l}\text { Vol. fraksi } \\
\quad(\mathbf{m L})\end{array}$} & \multicolumn{3}{|c|}{ Rhodinol murni } & \\
\hline & $\underset{(\%)}{\text { Kadar }}$ & $\begin{array}{c}\text { Vol. } \\
(\mathbf{m L})\end{array}$ & $\begin{array}{c}\text { Jumlah } \\
(\mathrm{g})\end{array}$ & & & $\underset{(\%)}{\text { Kadar }}$ & $\begin{array}{c}\text { Vol. } \\
(\mathbf{m L})\end{array}$ & $\begin{array}{l}\text { Rende- } \\
\text { men (g) }\end{array}$ & \\
\hline \multirow[t]{5}{*}{400} & 61,70 & 246,80 & 213,48 & F 210 & 3 & 43,59 & 1,31 & 1,13 & 0,53 \\
\hline & & & & F 225 & 2,5 & 68,20 & 1,71 & 1,47 & 0,69 \\
\hline & & & & F 230 & 200 & 74,86 & 149,72 & 129,51 & 60,66 \\
\hline & & & & $\begin{array}{l}\text { F } 240 \\
\text { R }\end{array}$ & $\begin{array}{l}62,5 \\
108\end{array}$ & $\begin{array}{l}78,87 \\
36,49\end{array}$ & $\begin{array}{l}49,29 \\
39,41\end{array}$ & $\begin{array}{l}42,64 \\
34,09\end{array}$ & $\begin{array}{l}19,97 \\
15,97\end{array}$ \\
\hline & & & & Total & $376(94 \%)$ & - & 241,44 & 208,84 & 97.83 \\
\hline
\end{tabular}

Tabel 4. Pengaruh penurunan laju panas terhadap pergerakan suhu dan volume fraksi ringan

\begin{tabular}{cccc}
\hline Feed $(\mathbf{m L})$ & Laju panas $(\boldsymbol{\%})^{*}$ & Suhu $\left({ }^{\mathbf{0}} \mathbf{C}\right)$ & Vol. fraksi ringan $(\mathbf{m L})$ \\
\hline 500 & $20-18-18$ & $200-229$ & 25 \\
500 & $18-16-16$ & $223-229,8$ & 98 \\
500 & $20-18-17$ & $215,3-229,6$ & - \\
300 & $18,5-16,5-16,5$ & $227-229,7$ & - \\
300 & $18-16-16$ & $216,9-229$ & 58 \\
300 & $18-16,5-16,5$ & $212-229,4$ & 12
\end{tabular}

Keterangan: *berturut-turut pada tahap pemanasan, kesetimbangan, dan distilasi fraksi ringan

Tabel 5. Perhitungan volume tiap fraksi pada feed $300 \mathrm{~mL}$

\begin{tabular}{lcccccc}
\hline \multirow{2}{*}{ Feed 300 $\mathbf{~ m L}$} & \multicolumn{3}{c}{ Fraksi ringan } & \multicolumn{2}{c}{ Fraksi rhodinol } & Residu \\
\cline { 2 - 7 } & Awal & Sa & Sao & So & Go & Akhir \\
\hline Kadar hasil GC $(\%)$ & 0,069 & 0,574 & 21,086 & 20,144 & 41,556 & 15,815 \\
Kadar*300 =... mL & 0,21 & 1,72 & 63,26 & 60,43 & 124,67 & 47,45 \\
Volume fraksi $(\mathrm{mL})$ & & 65,19 & \multicolumn{2}{c}{185,10} & 47,45 \\
\hline
\end{tabular}

Keterangan: $\mathrm{Sa}=$ sitronelal, $\mathrm{Sao}=$ antara sitronelal-sitronelol, $\mathrm{So}=$ sitronelol, $\mathrm{Go}=$ geraniol 
Laju panas terpilih adalah $18-16-16 \%$ karena menghasilkan pergerakan suhu yang stabil (tidak cepat naik melewati $230^{\circ} \mathrm{C}$ ) sehingga diperoleh volume frakasi ringan yang cukup banyak. Jika laju pemanasan terlalu besar, suhu naik terlalu cepat sehingga komponen bertitik didih tinggi akan menguap bersama dengan komponen bertitik didih rendah, namun jika laju pemanasan terlalu kecil, proses akan berlangsung lama sehingga tidak efisien (Riyanto et al., 2012).

Langkah selanjutnya adalah menentukan waktu kesetimbangan. Pada tahap kesetimbangan, pita kolom mulai berputar sehingga menciptakan putaran ke arah bawah dan terjadi tumbukan antara molekul uap yang bergerak ke atas dengan refluks yang bergerak ke bawah berupa lapisan molekul cairan pada dinding dalam kolom. Pita putar juga akan menyapu refluks pada dinding kolom sehingga keadaan menjadi semakin homogen. Putaran dan tumbukan mengakibatkan terjadinya perpindahan panas dari molekul yang bertitik didih lebih tinggi (B) ke molekul yang bertitik didih lebih rendah (A) sehingga A yang terperangkap pada lapisan refluks akan menguap sedangkan B terkondensasi menjadi refluks. Perpindahan panas dan massa ini terjadi di sepanjang kolom sehingga penguapan lebih terseleksi, dengan kata lain proses rektifikasi menjadi semakin tajam (Yost, 1974; Song-lin et al., 2019). Komponen bertitik didih berdekatan membutuhkan waktu kesetimbangan (rektifikasi) yang lebih lama (BR Instrument, 2014).

Pengujian dilakukan secara duplo dengan feed $300 \mathrm{~mL}$, tekanan $3 \mathrm{mmHg}$, suhu potong fraksi ringan $160^{\circ} \mathrm{C}$, suhu potong fraksi rhodinol $230^{\circ} \mathrm{C}$, rasio refluks 1 : 1 . Hasil pengujian disajikan pada Gambar 4.

Hasil uji GC menunjukkan rata-rata kadar rhodinol tertinggi dihasilkan dari waktu kesetimbangan 30 menit, yaitu 78,88\%. Selain itu, waktu kesetimbangan 30 menit membutuhkan laju panas yang lebih tinggi karena AET mengalami penurunan saat laju panas sebesar $18-16 \%$, sedangkan saat laju panas sebesar $18-17 \%$, AET bergerak stabil. Hal ini dapat disebabkan oleh gerakan berputar di dalam kolom yang mendorong uap ke bawah, dimulai saat tahap kesetimbangan berlangsung. Semakin kecil laju panas dan semakin lama waktu kesetimbangan maka penguapan semakin lambat dan semakin sulit uap bergerak ke atas karena dorongan ke bawah yang lebih kuat.

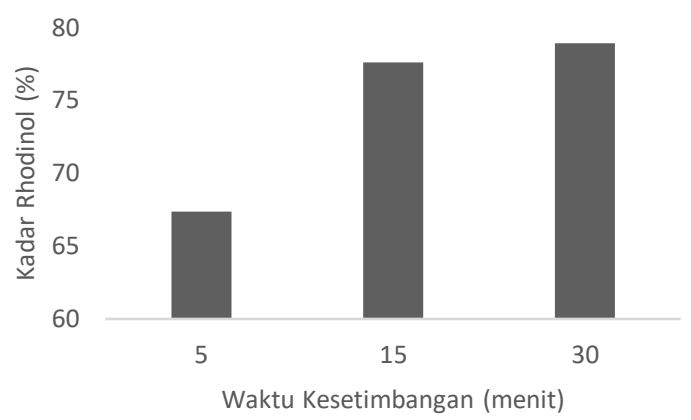

Gambar 4. Pengaruh waktu kesetimbangan (menit) terhadap kadar rhodinol

\section{Peningkatan Kadar dan Rendemen Rhodinol Melalui Rasio Refluks dan Suhu Potong Fraksi Rhodinol}

Berdasarkan analisis pergerakan suhu, dilakukan uji rasio refluks dan suhu potong fraksi rhodinol dengan parameter suhu potong fraksi ringan $160^{\circ} \mathrm{C}$, tekanan $3 \mathrm{mmHg}$, kesetimbangan 30 menit, laju panas $18-17 \%$, dan feed $300 \mathrm{~mL}$. Variabel rasio refluks yang diterapkan sebesar $3: 1$ dan $5: 1$, sedangkan variabel suhu potong fraksi rhodinol sebesar $230^{\circ} \mathrm{C}$ dan $235^{\circ} \mathrm{C}$. Pengujian dilakukan secara duplo. Perhitungan keseluruhan volume yang dihasilkan pada fraksi ringan (F1), fraksi rhodinol (F2), dan residu dari setiap variabel rasio refluks dan suhu potong disajikan pada Tabel 6 .

Hasil menunjukkan bahwa total loss yang terjadi selama proses distilasi pada spinning band sangatlah kecil, yaitu sekitar $4-11 \mathrm{ml}$ atau $1-3 \%$. Loss dapat diakibatkan oleh minyak yang menempel pada permukaan kolom maupun wadah penampung saat proses perpindahan bahan, perhitungan volume, maupun saat distilasi berlangsung karena adanya uap atau komponen volatil yang ikut tersedot ke dalam cold trap atau jalur vakum.

Tabel 6. Perolehan volume fraksi dan total loss pada setiap variabel rasio refluks dan suhu potong dengan feed $300 \mathrm{~mL}$

\begin{tabular}{llllllll}
\hline \multirow{2}{*}{ Refluks; suhu } & \multicolumn{2}{l}{ Volume fraksi hasil $(\mathbf{m L})$} & \multicolumn{3}{c}{ Loss $^{\text {b }}$} \\
\cline { 2 - 8 } & F1 & F2 & Residu & Total & $(\boldsymbol{\%})^{\mathbf{a}}$ & $(\mathbf{m L})$ & $(\boldsymbol{\%})$ \\
\hline $3: 1 ; 230{ }^{\circ} \mathrm{C}$ & 65,50 & 166,50 & 57,00 & 289,00 & 96,33 & 11,00 & 3,67 \\
$3: 1 ; 235{ }^{\circ} \mathrm{C}$ & 75,00 & 161,50 & 52,00 & 288,50 & 96,17 & 11,50 & 3,83 \\
$5: 1 ; 230{ }^{\circ} \mathrm{C}$ & 72,00 & 166,00 & 57,50 & 295,50 & 98,50 & 4,50 & 1,50 \\
$5: 1 ; 235{ }^{\circ} \mathrm{C}$ & 84,50 & 157,50 & 51,50 & 293,50 & 97,83 & 6,50 & 2,17 \\
\hline
\end{tabular}

Keterangan:

apersentase volume fraksi hasil dan residu terhadap volume feed, ${ }^{\mathrm{b}}$ feed dikurangi

fraksi hasil dan residu 
Neraca massa rhodinol dihitung berdasarkan perolehan volume fraksi rhodinol. Kadar, rendemen, dan recovery rhodinol tertinggi dihasilkan oleh rasio refluks 5 : 1 pada suhu potong $230{ }^{\circ} \mathrm{C}$, yaitu berturutturut sebesar $81,30 \%, 116,78 \mathrm{~g}$, dan 72,94\%. Kadar rhodinol yang dihasilkan sudah cukup memenuhi kadar minimal perdagangan global, namun sedikit di bawah standar WHO. Spesifikasi rhodinol yang berada di pasar sampai saat ini beragam: kadar minimal WHO (2004) sebesar 82\%, The Good Scents Company (2019) sebesar 70 - 100\%, Ernesto Ventos memproduksi rhodinol dengan kadar sitronelol 12 $25 \%$ dan geraniol $28-48 \%$, sedangkan Bedoukian memiliki standar rhodinol dengan kadar sitronelol $56 \%$ dan geraniol $37-43 \%$. Rata-rata kadar dan rendemen rhodinol yang dihasilkan pada fraksi rhodinol terdapat pada Tabel 7.

Rasio refluks memengaruhi kemurnian distilat karena terbentuk refluks yang menciptakan rektifikasi. Rasio refluks yang terlalu kecil dapat menyebabkan terjadinya pemisahan komponen yang kurang murni karena masih memiliki kandungan komponen lain yang tidak diinginkan, sedangkan rasio refluks yang terlalu tinggi akan menghasilkan proses pemisahan yang terlalu lama sehingga memungkinan beberapa komponen terdegradasi akibat panas (Gilbert dan Martin, 2010; Amrullah et al., 2017). Hal ini ditunjukkan pada suhu $235^{\circ} \mathrm{C}$ dimana rasio refluks $5: 1$ menghasilkan kadar dan rendemen rhodinol yang lebih rendah dari $3: 1$.

Suhu potong yang terlalu tinggi juga dapat mengakibatkan degradasi bahan karena akan membutuhkan laju panas dan suhu labu yang lebih tinggi. Suhu $230^{\circ} \mathrm{C}$ lebih efektif memisahkan rhodinol daripada suhu $235^{\circ} \mathrm{C}$, hal ini sesuai dengan Perry dan Green (1999), Maloney (2008), dan Kirk (1954) diacu dalam Ketaren (1985) yang menyatakan titik didih geraniol terdapat pada suhu $230^{\circ} \mathrm{C}$.

Berdasarkan hasil penelitian ini, fraksinasi komponen minyak sereh wangi menggunakan spinning band distillation column menunjukkan hasil yang lebih efektif dalam meningkatkan kemurnian dan rendemen rhodinol dengan loss yang lebih kecil dibandingkan menggunakan fraksinasi vakum dan distilasi molekular pada penelitian sebelumnya. Proses pemurnian atau isolasi secara fisik menggunakan spinning band distillation colum selain lebih efektif juga lebih efisien karena tidak perlu menggunakan pelarut atau bahan lain (Savarkar et al., 2017).

\section{KESIMPULAN DAN SARAN}

\section{Kesimpulan}

Kondisi proses terbaik untuk mengisolasi rhodinol menggunakan spinning band distillation column tipe $9600 \mathrm{~B} / \mathrm{R}$ Instrument adalah pada suhu potong fraksi ringan $160{ }^{\circ} \mathrm{C}$, tekanan $3 \mathrm{mmHg}$, laju panas $18-17 \%$, dan kesetimbangan 30 menit. Kondisi ini menghasilkan pergerakan suhu AET yang stabil pada suhu titik didih tiap komponen utama. Rasio refluks 5 : 1 pada suhu $235{ }^{\circ} \mathrm{C}$ menghasilkan kadar dan recovery rendemen rhodinol tertinggi yaitu sebesar $81,30 \%$ dan $72,94 \%$. Hasil ini sesuai dengan konsep rasio refluks dimana semakin besar rasio refluks yang digunakan maka semakin tinggi kemurniannya. Suhu penguapan yang terpilih pun sesuai dengan titik didih geraniol yaitu $230{ }^{\circ} \mathrm{C}$. Penelitian ini juga menunjukkan pemurnian rhodinol yang lebih efektif dibandingkan penelitian sebelumnya yang menggunakan fraksinasi vakum dan distilasi molekular karena mampu meningkatkan kemurnian rhodinol yang lebih besar melalui satu tahap fraksinasi dengan rendemen yang lebih tinggi dan loss yang kecil $(1-3 \%)$.

\section{Saran}

Penelitian selanjutnya dapat dilakukan dengan waktu kesetimbangan yang lebih lama, rasio refluks yang lebih tinggi, juga dapat dilakukan pemotongan fraksi berdasarkan variabel volume distilat. Waktu kesetimbangan dapat dibuat menjadi variabel dengan beberapa level yang lebih lama untuk diperoleh titik optimumnya. Selain itu, dapat dilakukan redistilasi fraksi rhodinol untuk mendapatkan kemurnian yang lebih tinggi.

\section{UCAPAN TERIMA KASIH}

Terima kasih kepada Kepala Balai Besar Kimia dan Kemasan (BBKK) atas kerjasama penggunaan alat spinning band distillation serta kepada bagian Product Engineering PT.Indesso Aroma - Cileungsi atas kerjasama dalam pengadaan bahan baku dan analisis $G C$.

Tabel 7. Neraca massa rhodinol pada fraksi rhodinol

\begin{tabular}{|c|c|c|c|c|c|c|c|}
\hline \multirow{2}{*}{$\begin{array}{c}\text { Rasio refluks; } \\
\text { suhu } \\
\left({ }^{\circ} \mathrm{C}\right)\end{array}$} & \multicolumn{3}{|c|}{ Fraksi kaya rhodinol $($ feed $)$} & \multicolumn{3}{|c|}{ Fraksi rhodinol } & \multirow{2}{*}{$\begin{array}{c}\text { Recovery rendemen } \\
\text { rhodinol }(\%)\end{array}$} \\
\hline & $\begin{array}{l}\text { Vol. } \\
(\mathrm{mL})\end{array}$ & $\begin{array}{c}\text { Kadar } \\
\text { feedrhodinol } \\
(\%)\end{array}$ & $\begin{array}{l}\text { Bobot } \\
\text { rhodinol } \\
\text { (g) }\end{array}$ & $\begin{array}{l}\text { Vol. } \\
\text { fraksi } \\
(\mathrm{mL})\end{array}$ & $\begin{array}{l}\text { Kadar } \\
\text { rhodinol } \\
(\%)\end{array}$ & $\begin{array}{l}\text { Rendemen } \\
\text { rhodinol (g) }\end{array}$ & \\
\hline $3: 1 ; 230$ & & & & 166,50 & 79,81 & 114,99 & 71,82 \\
\hline $3: 1 ; 235$ & 300 & 61,70 & 160,11 & 161,50 & 80,53 & 112,57 & 70,31 \\
\hline $5: 1 ; 230$ & & & & 166,00 & 81,30 & 116,78 & 72,94 \\
\hline $5: 1 ; 235$ & & & & 157,50 & 80,21 & 109,24 & 68,23 \\
\hline
\end{tabular}




\section{DAFTAR PUSTAKA}

Amanatur R, Kusoro S, dan Sudarmin. 2014. Isolasi sitronelal dari minyak sereh dan oksidasinya dengan $\mathrm{KMnO}_{4}$ dalam suasana basa. Indonesian Journal Chemical Science. 3 (3). 198-202.

Amrullah R, Nurjanah S, Widyasanti A, Muhaemin M. 2017. Kajian pengaruh rasio refluks terhadap karakteristik minyak nilam hasil distilasi fraksinasi. Jurnal Teknotan. 11 (8): 77 -88 .

Beneti SC, Rosset E, Corazza ML, Frizzo CD, Luccio MD, Oliveira JV. 2011. Fractionation of citronella (Cymbopogon winterianus) essential oil and concentrated orange oil phase by batch vacuum distillation. Journal Food Engineering . 102 (4): 348-354.

Brechbill GO. 2009. Perfume Bases \& Fragrance Ingredients. New Jersey: Fragrance Books Inc.

BR Instrument. 2014. Handbook of Spinning Band Distillation Column B/R Instrument 9600. Maryland: B/R Instrument Inc.

BSN. 1987a. SNI 06-0026-Sitronelal. Jakarta: Dewan Standarisasi Nasional.

BSN. 1987b. SNI 06-0027-Geraniol. Jakarta: Dewan Standarisasi Nasional.

BSN. 1995. SNI 06-3953-Minyak Sereh. Jakarta: Dewan Standarisasi Nasional.

[Dirjen Perkebunan] Direktorat Jenderal Perkebunan. 2013. Statistik Perkebunan Indonesia 20122014: Tanaman Semusim. Jakarta: Departemen Pertanian.

Ferdayanti M, Sastrohamidjojo H, dan Riyanto. 2014. Pemekatan sitronelal dalam minyak sereh wangi (Cymbopogon nardus L.) dengan fraksinasi distilasi dan identifikasi menggunakan KG-SM. Indonesian Journal Chemical Research. 2 (1): 28-34.

Gibbs LM. 1983. Recovery Of Waste Organic Solvents In A Health Care Institution. American Clinical Review. Vol 2.6 : 37. Connecticut: International Scientific Communication Inc.

Harris R.1994. Tanaman Minyak Atsiri. Jakarta: Penebar Swadaya.

Kirk O. 1954. diacu dalam Ketaren S. 1985. Pengantar Teknologi Minyak Atsiri. Jakarta: PN Balai Pustaka.

Ketaren S. 1985. Pengantar Teknologi Minyak Atsiri. Jakarta: PN Balai Pustaka.

Maloney JO. 2008. Perry's Chemical Engineering Handbook. $8^{\text {th }}$ ed. New York: McGraw-Hill Company.

Muyassaroh. 2010. Sitronellal dari minyak sereh wangi dengan variasi kecepatan pengadukan dan penambahan natrium bisulfit. Fakultas Teknologi Industri, Institut Teknologi Nasional.
Ozek T. 2013. Extraction, Separation and Analysis Techniques for MAPs: from Field to Market. Regonal Expert Consultation on Medicinal and Aromatic Plants, 13-15 November. Antalya, Turkey.

Perry RH dan Green D. 1999. Perry's Chemical Engineering Handbook. New York (US): Mc Graw-Hill Company.

Riyanto A, Yunilawati R, dan Nuraeni C. 2012. Isolasi Metil Sinamat dari Minyak Atsiri Laja Gowah (Alpinia malaccensis (Burm.F.)). Jurnal Kimia Kemasan. cvf34(2): 237 - 242.

Rusli MS. 2010. Sukses Memproduksi Minyak Atsiri. Jakarta: Agromedia Pustaka

Rusli MS. 2015. Potensi Minyak Atsiri Indonesia dan Peran DAI. Dalam Seminar Sehari Prospek Bisnis Minyak Atsiri 2015, IPB-ICC Bogor.

Savarkar PP, Kharade SG, Talap PP, Moharir SR, Suryawanshi MA. 2017. Study of Spinning Band Distillation Column. IJAERD. 4: $1060-$ 1065.

Sayekti E, Sapar A, Fitririyanti, Zaharah TA. 2013. Isolasi Rhodinol Dari Minyak Sereh Jawa Menggunakan Metode Kromatografi Kolom Tekan. Prosiding Semirata FMIPA. Lampung (ID): Universitas Lampung.

Song-lin XU, Xiao-fei Q, Tao L, Xiao-guang L. 2009. Liquid Flow Regimes on Wall of Spinning Band Distillation Column. Journal Tianjin University. 42(5): $444-447$.

Sulaswatty A, Rusli MS, Abimanyu H, Tursiloadi S. 2019. Quo Vadis Minyak Sereh Wangi dan Produk Turunannya. Jakarta: LIPI Press.

The Good Scents Company. 2019. Fragrance and Flavor Demo Formulas. [internet]. [diacu 2019 Maret 03]. Tersedia pada: http://www.thegoodscentscompany.com/data/ rw1010451.html.

[US EPA] U.S. Enviromental Protection Agency. 2009. Screening-Level Hazard Characterization: Terpenoid Primary Alcohols and Related Esters Category. Washington DC (US): US EPA.

Weng DCJ, Latip J, dan Hasbullah SA, Sastrohamidjojo H. 2015. Separation of geraniol from citronellol by selective oxidation of geraniol to geranial. Sains Malaysiana. 44(8): 1183 - 1188.

[WHO] World Health Organization. 2004. Evaluation of Certain Food Additives and Contaminants. Swiss: WHO.

Yao L dan Hammond EG. 2006. Isolation and Melting Properties of Branched-Chain Esters from Lanolin. JAOCS . 83(6): 547.

Yost RW. 1974. Distillation Primer: A Survey of Distillation Systems. Amerika (USA): American Laboratory. 